\title{
Interstitial lung disease before and after COVID-19: a double threat?
}

\author{
Claudia Valenzuela ${ }^{1}$, Grant Waterer ${ }^{2}$ and Ganesh Raghu ${ }^{3}$ \\ ${ }^{1}$ ILD Unit, Pulmonology Dept Hospital Universitario de la Princesa, University Autonoma de Madrid, Madrid, Spain. ${ }^{2}$ University of Western \\ Australia, Royal Perth Hospital, Perth, Australia. ${ }^{3}$ Center for Interstitial Lung Diseases, University of Washington, Seattle, WA, USA.
}

Corresponding author: Ganesh Raghu (graghu@uw.edu)
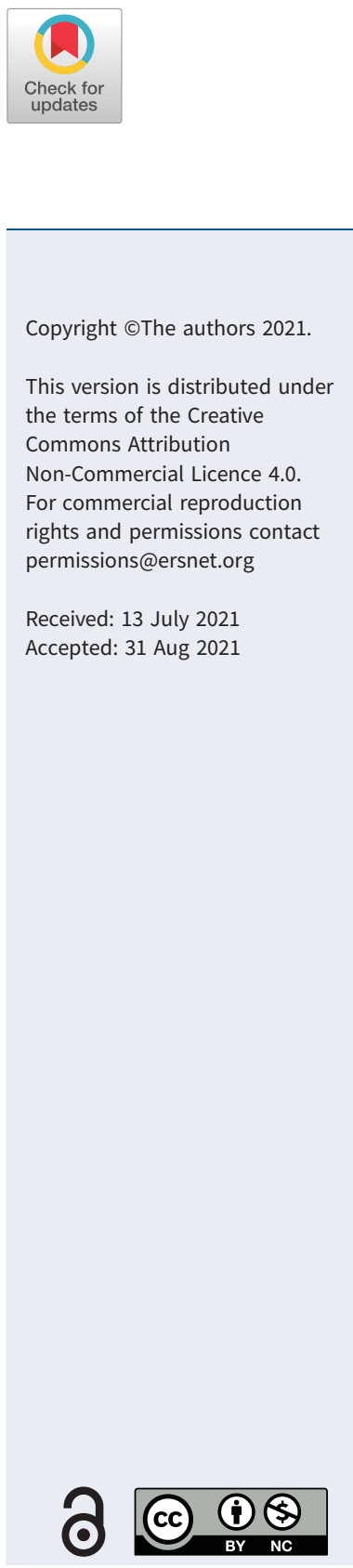

Shareable abstract (@ERSpublications)

Pre-existing ILD and pulmonary fibrosis increases the risk to manifest severe COVID-19. Residual interstitial lung changes and sequelae have been observed in COVID-19 survivors. A closer and standardised long-term follow-up of these patients is needed. https://bit.ly/3jWBPCG

Cite this article as: Valenzuela C, Waterer G, Raghu G. Interstitial lung disease before and after COVID19: a double threat? Eur Respir J 2021; 58: 2101956 [DOI: 10.1183/13993003.01956-2021].

\section{Introduction}

Sadly, there have already been nearly 200 million confirmed cases of coronavirus disease 2019 (COVID-19) and more than 4 million deaths [1]. The true toll is certainly much higher. We have learned much about the wide spectrum of disease due to COVID-19 over the past 18 months, ranging from asymptomatic infection to severe pneumonia, respiratory failure and death [2]. There is growing concern about whether survivors of COVID-19 will have long-term pulmonary sequelae, including fibrotic interstitial lung disease (ILD) and/or manifest progressive pulmonary fibrosis [3].

Several clinical features and comorbidities are associated with a poor prognosis and a higher risk of mortality of COVID-19. These include pre-existing health problems such as hypertension, diabetes, cardiovascular disease, obesity, cancer, chronic kidney, liver and lung diseases, and older age, male sex, smoking and race [4-7]. Whether these risk factors are also predictors of longer-term outcomes from COVID-19 is currently unclear. Although bilateral parenchymal airspace densities, organising pneumonia, and diffuse alveolar damage are known acute features of COVID-19 [8], their severity and duration need to be determined.

Three important clinical questions have arisen around the interaction between COVID-19 and ILD: 1) Are patients with pre-existing ILD at higher risk of pulmonary complications from COVID-19? 2) Do survivors of COVID-19 without known pre-existing ILD manifest pulmonary fibrosis? and 3) What is the appropriate management of post-COVID-19 interstitial lung changes?

Are patients with pre-existing ILD at higher risk of pulmonary complications from COVID-19? While COPD has been associated with poor outcomes as a consequence of COVID-19 [7], data on patients with ILD are limited. As patients with ILD have both impaired lung function and increased risk of acute exacerbations driven by viral infection, COVID-19 is of particular concern [9].

In this issue of the European Respiratory Journal, LeE et al. [10] investigated the relationship between ILD and COVID-19. They report on a Korean nationwide cohort of 8070 patients with COVID-19, and an age, sex and region-matched cohort derived from a pool of 121050 subjects. Of the 8070 COVID-19 patients, $67(0.8 \%)$ had ILD. Their findings suggest that patients with ILD have a higher risk of both acquiring COVID-19 and having worse outcomes. The reason for patients with ILD to have an apparently increased susceptibility is unclear. However, patients with ILD were over-represented in the COVID-19 cohort $(0.8 \%$ versus $0.4 \%$ ), with an adjusted odds ratio of 2.02 (95\% CI 1.54-2.61). As there is no theoretical reason that patients with pre-existing ILD would be more frequently infected with SARS-CoV-2, this observation suggests that ILD may predispose to develop more symptomatic disease. 
Not surprisingly, COVID-19 patients with pre-existing ILD required more often oxygen therapy (46.3\% versus $12.3 \%$ ), had a higher rate of intensive care unit admission (10.5\% versus $2.9 \%$ ) and mechanical ventilation (11.9\% versus $1.9 \%$ ), and a higher mortality (43.3\% versus $13.1 \%)$. Using a composite end-point, they showed that patients with ILD were more likely to have severe COVID-19 than those without (adjusted OR 2.23, 95\% CI 1.24-4.01), including those with idiopathic pulmonary fibrosis (IPF) (adjusted OR 14.82, 95\% CI 3.96-63.74) [10].

Other studies have reported similar findings (table 1). In a European multicentre study, DraKe et al. [11] found that pre-existing ILD was associated with significantly higher mortality from COVID-19. A four-fold increase in the adjusted risk of death in patients with pre-existing ILD was found in another case-control study of 46 patients with COVID-19 and 92 controls [12]. More recently, GaLlay et al. [13] reported a case fatality rate of 35\% among subjects with idiopathic fibrotic ILD and 19\% in those with other ILDs, the latter being comparable to that reported in the global French population hospitalised for COVID-19 at that time.

These prior studies and the report by LeE et al. [10] confirm that ILD patients, most of them requiring hospitalisation, have worse outcomes from COVID-19. This knowledge should alert clinicians and patients of their particular need to minimise risks for exposure to SARS-CoV-2 by taking appropriate proactive, preventive measures, including vaccination [14].

\section{TABLE 1 Published reports on pre-existing interstitial lung disease (ILD) and COVID-19}

\begin{tabular}{|c|c|c|c|c|c|}
\hline Study & Type of study & Country & Population/data & Key results & Risk factors for mortality \\
\hline $\begin{array}{l}\text { Esposito } \\
\text { et al. } \\
\text { [12] }\end{array}$ & $\begin{array}{l}\text { Multicentre retrospective } \\
\text { case-control study, } \\
1 \text { March to } 8 \text { June, } \\
2020\end{array}$ & $\begin{array}{l}\text { USA ( } 6 \text { centres in } \\
\text { Boston, MA) }\end{array}$ & $\begin{array}{l}\text { Hospitalised and non } \\
\text { hospitalised patients } \\
\text { - } 46 \text { COVID-19/ILD } \\
\text { - } 92 \text { COVID-19/non-ILD } \\
\text { (controls matched for age, } \\
\text { sex, and race) }\end{array}$ & $\begin{array}{l}\text { Mortality } \\
\text { - coVID-19/ILD 33\% } \\
\text { - coVID-19/non-ILD } \\
13 \% \\
\text { Increased aOR of death } \\
4.3(95 \% \text { CI 1.4-14.0; } \\
\text { p=0.01) } \\
\text { Likely to be } \\
\text { hospitalised } \\
\text { - coVID-19/ILD 74\% } \\
\text { - cOVID-19/non-ILD } \\
58 \% \\
\text { Need for ICU } \\
\text { - COVID-19/ILD 47\% } \\
\text { - COVID-19/non-ILD } \\
\text { 23\% }\end{array}$ & $\begin{array}{l}\text { - Older ages } \\
\text { - Lower } D_{\text {LCO }} \\
\text { UIP pattern in CT scan } \\
\text { (although not statistically } \\
\text { different from survivors) }\end{array}$ \\
\hline $\begin{array}{l}\text { DraKE } \\
\text { et al. } \\
\text { [11] }\end{array}$ & $\begin{array}{l}\text { International } \\
\text { multicentre analysis, } \\
1 \text { March to } 1 \text { May, } \\
2020\end{array}$ & $\begin{array}{l}\text { UK and European } \\
\text { ILD centres }\end{array}$ & $\begin{array}{l}\text { Hospitalised patients } \\
\text { - } 161 \text { COVID-19/ILD } \\
\text { - } 322 \text { COVID-19/non-ILD } \\
\text { (propensity-score matched } \\
\text { for age, sex, and } \\
\text { comorbidities) }\end{array}$ & $\begin{array}{l}\text { Mortality } \\
\text { - cOVID-19/ILD 49\% } \\
\text { - coVID-19/non-ILD } \\
35 \% \\
\text { Increased risk of death } \\
\text { in adjusted analysis } \\
\text { (HR 1.60, 95\% Cl } \\
1.17-2.18 ; p=0.003 \text { ) }\end{array}$ & $\begin{array}{l}\text { - Male sex } \\
\text { - Older age } \\
\text { - Obesity } \\
\text { - IPF } \\
\text { - FVC }<80 \% \text { pred }\end{array}$ \\
\hline $\begin{array}{l}\text { GaLlay } \\
\text { et al. } \\
\text { [13] }\end{array}$ & $\begin{array}{l}\text { Multicentric } \\
\text { observational survey, } \\
\text { from onset of the } \\
\text { outbreak in France to } \\
28 \text { May, } 2020\end{array}$ & $\begin{array}{l}\text { France: French } \\
\text { rare lung } \\
\text { disease } \\
\text { network } \\
\text { (OrphaLung) }\end{array}$ & $\begin{array}{l}123 \text { COVID-19/ILD } \\
\text { - } 48 \text { fibrotic idiopathic ILD } \\
\text { - } 75 \text { other types of ILD }\end{array}$ & $\begin{array}{l}\text { Mortality at } 30 \text { days } \\
\text { - Fibrotic idiopathic ILD } \\
35 \% \\
\text { - Other types of ILD } \\
19 \% \\
\text { Hospital admission } \\
\text { - } 84 \% \text { ( } 21 \% \text { in ICU) } \\
\text { - } 90 \% \text { fibrotic } \\
\text { idiopathic ILD } \\
\text { - } 80 \% \text { other types } \\
\text { of ILD }\end{array}$ & $\begin{array}{l}\text { - Increasing age } \\
\text { - Male sex } \\
\text { - History of cancer/ } \\
\text { haemopathy } \\
\text { - Chronic use of oxygen } \\
\text { supplementation at } \\
\text { home }\end{array}$ \\
\hline
\end{tabular}

aOR: adjusted odds ratio; HR: hazard ratio; ICU: intensive care unit; $D_{\mathrm{LCO}}$ : diffusing capacity of the lung for carbon monoxide; UIP: usual interstitial pneumonia; CT: computed tomography; IPF: idiopathic pulmonary fibrosis; FVC: forced vital capacity. 
Do survivors of COVID-19 without pre-existing ILD manifest pulmonary fibrosis?

Several observational studies have reported the natural course of patients recovering from COVID-19, with results varying from full recovery to lung function impairment and persistence of air space densities and pulmonary fibrosis (table 2). Interstitial lung and fibrotic abnormalities have been described after infection by other coronaviruses, such as SARS-CoV-1 in 2002 and MERS-CoV in 2012, in approximately one third of patients $[15,16]$.

Factors predicting evolution of COVID-19 pneumonitis were first reported by MARVISI et al. [17] in 90 hospitalised patients. In another study, preliminary data at follow-up from a cohort of 837 COVID-19 patients revealed that 325 (39\%) had persistent symptoms. At 6 weeks from discharge, persistent parenchymal abnormalities were found in 59 (76.6\%) of 77 patients assessed in the ILD service who had an abnormal chest computed tomography (CT), predominantly suggesting organising pneumonia; 30 of

TABLE 2 Published reports on interstitial lung disease (ILD) in survivors of COVID-19 without pre-existing ILD

\begin{tabular}{|c|c|c|c|c|c|}
\hline Study & Type of study & Country & Population/data & Duration of the study & Results \\
\hline $\begin{array}{l}\text { MARVISI } \\
\text { et al. } \\
\text { [17] }\end{array}$ & $\begin{array}{l}\text { Restrospective evaluation } \\
\text { of clinical and HRCT } \\
\text { features }\end{array}$ & Italy & 90 Caucasian patients & Admission and 8 weeks later & $\begin{array}{l}\text { - Pulmonary fibrosis }(n=23 \text { ) } \\
25 \% \\
\text { - } 15 \text { were males with age } \\
75 \pm 15 \text { years } \\
\text { - GGOs in } 90 \% \text { on admission } \\
\text { - Residual GGOs in } ~ 50 \% \text { at } \\
8 \text { weeks }\end{array}$ \\
\hline $\begin{array}{l}\text { LeRum et al. } \\
\quad[20]\end{array}$ & $\begin{array}{l}\text { Prospective trial; } \\
\text { self-reported dyspnoea, } \\
\text { QOL, pulmonary } \\
\text { function and chest CT } \\
\text { findings }\end{array}$ & Norway & 103 patients & $\begin{array}{l}3 \text { months following hospital } \\
\text { admission for COVID-19 }\end{array}$ & $\begin{array}{l}\text { - Parenchymal bands in } 19 \% \\
\text { - Residual GGOs in } 25 \% \\
\text { - Median FVC, FEV } 1 \text { and } D_{\text {Lco }} \\
\text { were } 94 \%, 92 \% \text { and } 83 \% \\
\text { pred, respectively }\end{array}$ \\
\hline $\begin{array}{l}\text { HAN et al. } \\
\text { [19] }\end{array}$ & $\begin{array}{l}\text { Assessed pulmonary } \\
\text { sequelae and risk } \\
\text { factors for fibrotic-like } \\
\text { changes }\end{array}$ & UK & 114 patients & $\begin{array}{l}\text { At } 6 \text { months after severe } \\
\text { COVID-19 pneumonia }\end{array}$ & $\begin{array}{l}\text { - Fibrotic-like changes in 35\% } \\
\text { - Residual GGOs/interstitial } \\
\text { thickening in } 27 \% \\
\text { - Complete resolution in } 38 \%\end{array}$ \\
\hline $\begin{array}{l}\text { Myall et al. } \\
\text { [18] }\end{array}$ & $\begin{array}{l}\text { Observational study of } \\
\text { corticosteroid treatment }\end{array}$ & UK & 837 COVID-19 patients & $\begin{array}{l}\text { Assessed via telephone } 4 \text { weeks } \\
\text { after discharge; } 77 \text { patients } \\
\text { referred to post-COVID-19 } \\
\text { lung disease MDT after CT at } \\
6 \text { weeks }\end{array}$ & $\begin{array}{l}\text { - } 39 \%(325 / 837) \text { reported } \\
\text { ongoing symptoms } \\
\text { - } 59(76.6 \%) \text { of those imaged } \\
\text { at } 6 \text { weeks were found to } \\
\text { have persistent } \\
\text { parenchymal abnormality } \\
\text { - } 30 \text { of these patients } \\
\text { received steroid treatment } \\
\text { based on CT scan } \\
\text { (prednisolone } \\
0.5 \mathrm{mg} \cdot \mathrm{kg}^{-1} \text { with rapid } \\
\text { wean over } 3 \text { weeks) }\end{array}$ \\
\hline $\begin{array}{l}\text { SONNWEBER } \\
\text { et al. } \\
\text { [21] }\end{array}$ & $\begin{array}{l}\text { Prospective, multicentre, } \\
\text { observational study }\end{array}$ & Austria & $\begin{array}{l}145 \text { COVID-19 patients } \\
\text { (133 follow-up at } 100 \\
\text { days) }\end{array}$ & $\begin{array}{l}60 \text { and } 100 \text { days after confirmed } \\
\text { diagnosis }\end{array}$ & $\begin{array}{l}\text { - } 41 \% \text { persistent symptoms } \\
\text { at } 100 \text { days } \\
\text { - } 63 \% \text { radiological lung } \\
\text { abnormalities (GGOs, } \\
\text { consolidation and } \\
\text { reticulation) } \\
\text { - Majority of COVID-19 } \\
\text { patients improved } \\
\text { symptoms and lung } \\
\text { abnormalities within } \\
3 \text { months }\end{array}$ \\
\hline $\begin{array}{l}\text { Wu et al. } \\
\text { [22] }\end{array}$ & $\begin{array}{l}\text { Prospective, longitudinal, } \\
\text { follow-up study, }\end{array}$ & China & $\begin{array}{l}399 \text { patients admitted to } \\
\text { hospital (severe } \\
\text { COVID-19); } 135 \text { (34\%) } \\
\text { patients met the } \\
\text { inclusion criteria }\end{array}$ & $\begin{array}{l}\text { Follow-up at } 3,6,9 \text { and } \\
12 \text { months }\end{array}$ & $\begin{array}{l}\text { - } 65(78 \%) \text { had residual } \\
\text { changes on CT at } 3 \\
\text { months (mostly GGO) } \\
\text { - } 20(24 \%) \text { patients had } \\
\text { abnormal radiological } \\
\text { changes at } 12 \text { months }\end{array}$ \\
\hline
\end{tabular}

(HR)CT: (high-resolution) computed tomography; QOL: quality of life; MDT: multidisciplinary team; GGO: ground-glass opacity; FVC: forced vital capacity; $\mathrm{FEV}_{1}$ : forced expiratory volume in $1 \mathrm{~s} ; D_{\mathrm{Lco}}$ : diffusing capacity of the lung for carbon monoxide. 
them received treatment with corticosteroids and had improvement of forced vital capacity and carbon monoxide transfer factor after 3 weeks [18]. These findings, observed relatively soon after discharge, are therefore somewhat expected, and in keeping with studies of survivors of acute respiratory distress syndrome (ARDS) from other similar viral infections.

Recently, Han et al. [19] assessed pulmonary sequelae at chest CT at 6-month follow-up in 114 survivors of severe COVID-19 pneumonia, and found fibrotic-like changes on chest CT in 35\% of patients; $27 \%$ had residual ground-glass opacities or interstitial thickening, and only 38\% had complete radiological resolution. Variables associated with lung fibrotic changes at 6 months identified by multivariable analysis included age over 50 years, heart rate $>100$ beats per min at admission, hospital stay of 17 days or more, ARDS, noninvasive ventilation, and an initial total CT score equal to or greater than 18.

Recent reports demonstrated an improvement of symptoms and of CT abnormalities at 3 months and over 6-12 months in patients who survived COVID-19 [20-22]. Persistent radiological changes were found in $24 \%$ of 83 patients at 12 months after discharge [22].

What is the appropriate management of post-COVID-19 interstitial lung changes? Radiological and histological features observed in the acute phase of COVID-19 pneumonia correspond to the hyper-inflammation phase of the disease, and corticosteroid therapy has been the first line treatment since the findings of the RECOVERY trial [23]. However, management after the initial phase is not well established. In post-COVID-19 follow-up, our clinical experience and some emerging data suggest that persistent changes mostly consist of ground-glass opacities or consolidations corresponding to organising pneumonia at imaging, and corticosteroids may be beneficial in a number of cases [18]. In isolated cases, genuine pulmonary fibrosis may occur, although it seems to be less frequent than initially speculated [24]. It is currently unknown whether antifibrotic drugs indicated and used for IPF, other fibrotic ILDs with a progressive phenotype, and systemic sclerosis-associated ILD, also have a role in the treatment of fibrotic ILD following COVID-19 [24]. Results of ongoing clinical trials are eagerly awaited to determine the risk and benefits of antifibrotic treatment in patients with fibrotic lung involvement following COVID-19 (pirfenidone versus placebo: NCT04607928 and NCT04652518; nintedanib: NCT04541680 and NCT04619680; and comparing both antifibrotics: NCT04856111). More data is also likely to become available on the impact of acute COVID-19 therapies on long-term pulmonary outcomes, with particular interest in drugs that affect immune function, such as corticosteroids, tocilizumab and tofacitinib [23, 25, 26].

\section{Future directions}

Evolving knowledge raises the concern of residual pulmonary sequelae in survivors of COVID-19. Monitoring disease course longitudinally in survivors of COVID-19 will hopefully shed useful insights and enhance our understanding of the factors driving the resolution, evolution or stability of pulmonary fibrosis following COVID-19 [27]. Prospective, clinical, physiological and radiological assessment of the lung in well-designed studies is needed to differentiate fibrotic sequelae without physiological impairment in asymptomatic patients from fibrosis associated with functional impairment and reduction in quality of life. The efficacy and safety of antifibrotic agents in the setting of COVID-19 need to be determined in well-designed studies.

\section{Summary}

The report by LEE et al. [10] in this issue of the European Respiratory Journal highlights that pre-existing ILD increases the risk of manifesting severe COVID-19. Therefore, this is a group of patients in whom additional preventive measures, such as vaccination, is particularly indicated.

Emerging data documenting the residual interstitial lung changes and sequelae warrant future studies to determine the risk of pulmonary fibrosis in COVID-19 survivors. The need for a close and standardised long-term follow-up of these patients to understand disease behaviour is evident.

Conflict of interest: C. Valenzuela reports personal fees for consultancy and lectures from Boehringer Ingelheim, F. Hoffmann-La Roche, Ltd and BMS, outside the submitted work. G. Waterer reports personal fees for consultancy from Union Therapeutics, personal fees for lectures from GSK, outside the submitted work. G. Raghu reports personal fees for consultancy from Boehringer Ingelheim, Roche-Genentech and PureTech Health, outside the submitted work. 
References

1 World Health Organization. WHO Coronavirus Disease (COVID-19) Dashboard. https://covid19.who.int/ Date last accessed: 14 May 2021.

2 Guan W-J, Ni Z-y, Hu Y, et al. Clinical characteristics of coronavirus disease 2019 in China. N Engl J Med 2020; 82: $1708-1720$.

3 Spagnolo P, Balestro E, Aliberti S, et al. Pulmonary fibrosis secondary to COVID-19: a call to arms? Lancet Respir Med 2020; 8: 750-752.

4 Richardson S, Hirsch JS, Narasimhan M, et al. Presenting characteristics, comorbidities, and outcomes among 5700 patients hospitalized with COVID-19 in the New York City area. JAMA 2020; 323: 2052-2059.

5 Docherty AB, Harrison EM, Green CA, et al. Features of 20133 UK patients in hospital with covid-19 using the ISARIC WHO Clinical Characterisation Protocol: prospective observational cohort study. BMJ 2020; 369: m1985.

6 Sze S, Pan D, Nevill CR, et al. Ethnicity and clinical outcomes in COVID-19: a systematic review and meta-analysis. EClinicalMedicine 2020; 29: 100630.

7 Sanchez-Ramirez DC, Mackey D. Underlying respiratory diseases, specifically COPD, and smoking are associated with severe COVID-19 outcomes: a systematic review and meta-analysis. Respir Med 2020; 171: 106096.

8 Konopka KE, Nguyen T, Jentzen JM, et al. Diffuse alveolar damage (DAD) resulting from coronavirus disease 2019 infection is morphologically indistinguishable from other causes of DAD. Histopathology 2020; 77: 570-578.

9 Collard HR, Ryerson CJ, Corte TJ, et al. Acute exacerbation of idiopathic pulmonary fibrosis. An international working group report. Am J Respir Crit Care Med 2016; 194: 265-275.

10 Lee $\mathrm{H}$, Choi H, Yang B, et al. Interstitial lung disease increases susceptibility to and severity of COVID-19. Eur Respir J 2021; 58: 2004125.

11 Drake TM, Docherty AB, Harrison EM, et al. Outcome of hospitalization for COVID-19 in patients with interstitial lung disease. An international multicenter study. Am J Respir Crit Care Med 2020; 202: 1656-1665.

12 Esposito AJ, Menon AA, Ghosh AJ, et al. Increased odds of death for patients with interstitial lung disease and COVID-19: a case-control study. Am J Respir Crit Care Med 2020; 202: 1710-1713.

13 Gallay L, Uzunhan Y, Borie R, et al. Risk factors for mortality after COVID-19 in patients with preexisting interstitial lung disease. Am J Respir Crit Care Med 2021; 203: 245-249.

14 Papiris SA, Bouros D, Markopoulou K, et al. Early COVID-19 lockdown in Greece and idiopathic pulmonary fibrosis: a beneficial 'impact' beyond any expectation. Eur Respir J 2021; 57: 2003111.

15 Das KM, Lee EY, Singh R, et al. Follow-up chest radiographic findings in patients with MERS-CoV after recovery. Indian J Radiol Imaging 2017; 27: 342-349.

16 Mineo G, Ciccarese F, Modolon C, et al. Post-ARDS pulmonary fibrosis in patients with H1N1 pneumonia: role of follow-up CT. Radiol Med 2012; 117: 185-200.

17 Marvisi M, Ferrozzi F, Balzarini L, et al. First report on clinical and radiological features of COVID-19 pneumonitis in a Caucasian population: factors predicting fibrotic evolution. Int J Infect Dis 2020; 99: 485-488.

18 Myall KJ, Mukherjee B, Castanheira AM, et al. Persistent post-COVID-19 interstitial lung disease. an observational study of corticosteroid treatment. Ann Am Thorac Soc 2021; 18: 799-806.

19 Han X, Fan Y, Alwalid O, et al. Six-month follow-up chest CT findings after severe COVID-19 pneumonia. Radiology 2021; 299: E177-E186.

20 Lerum TV, Aaløkken TM, Brønstad E, et al. Dyspnoea, lung function and CT findings 3 months after hospital admission for COVID-19. Eur Respir J 2021; 57: 2003448.

21 Sonnweber T, Sahanic S, Pizzini A, et al. Cardiopulmonary recovery after COVID-19: an observational prospective multicentre trial. Eur Respir J 2021; 57: 2003481.

22 Wu X, Liu X, Zhou Y, et al. 3-month, 6-month, 9-month, and 12-month respiratory outcomes in patients following COVID-19-related hospitalisation: a prospective study. Lancet Respir Med 2021; 9: 747-754.

23 RECOVERY Collaborative Group, Horby P, Lim WS, et al. Dexamethasone in hospitalized patients with Covid-19. N Engl J Med 2021; 384: 693-704.

24 George PM, Wells AU, Jenkins RG. Pulmonary fibrosis and COVID-19: the potential role for antifibrotic therapy. Lancet Respir Med 2020; 8: 807-815.

25 Salama C, Han J, Yau L, et al. Tocilizumab in patients hospitalized with covid-19 pneumonia. N Engl J Med 2021; 384: 20-30.

26 Guimarães PO, Quirk D, Furtado RH, et al. Tofacitinib in patients hospitalized with Covid-19 Pneumonia. N Engl J Med 2021; 385: 406-415.

27 Raghu G, Wilson KC. COVID-19 interstitial pneumonia: monitoring the clinical course in survivors. Lancet Respir Med 2020; 8: 839-842. 